\title{
SPORTSANTHROPOMETRIC AND PERFORMANCE PARAMETERS OF ELITE ROCK 'N' ROLL DANCERS
}

\author{
AnNA Fritzsche ${ }^{1}$, Jürgen FritzsChE ${ }^{2}$ \\ ${ }^{1}$ Austrian Rock ' $n$ ' Roll Federation, ${ }^{2}$ German Karate Federation
}

\begin{abstract}
Rock ' $n$ ' roll dancing is one of the technical compositional sports. The current state of scientific knowledge on it can be described as minimal. To change this state, the first sports science survey regarding squad training was conducted under the guidance of the authors at the Austrian national rock ' $n$ ' roll team. The study group consisted of $26 \mathrm{~A}, \mathrm{~B}$ and $\mathrm{C}$ level athletes in the sport of rock ' $n$ ' roll acrobatics. The mean BMI of the male athletes with the mean age of 23.0 years was $23.3 \mathrm{~kg} / \mathrm{m}^{2}$. The female subjects' mean age was 19.5 years and their mean BMI $19.8 \mathrm{~kg} / \mathrm{m}^{2}$. The bounce values of the men were as follows: squat jump (SQJ) $37.1 \mathrm{~cm}$ and counter- movement jump (CMJ) $41.9 \mathrm{~cm}$. Men's mean result in long jump was $256.0 \mathrm{~cm}$. The women had a lower mean bounce of $25.8 \mathrm{~cm}$ and $27.2 \mathrm{~cm}$ in SQJ and CMJ respectively. Their mean length of the long jump was $204.6 \mathrm{~cm}$.

The anthropometric data showed that the male subjects' mean body height was $1.81 \mathrm{~m}$ and weight $76.2 \mathrm{~kg}$. The BIA measurement yielded a value of $15.8 \%$ body fat. The women's mean height was $1.64 \mathrm{~m}$ and percentage of passive body substance $23.5 \%$; their mean weight was $53.4 \mathrm{~kg}$. The waist/hip ratio was 0.9 in both men and women. The Broca index was $1.2 \%$ in women and $6 \%$ in men. The AKS-index reached 1.02 in men and 0.91 in women.

Data were collected to determine the one-repetition maximum (1RM) of the upper and lower extremities: lat pulldowns (m: $76.9 \mathrm{~kg} ; \mathrm{w}: 39.4 \mathrm{~kg}$ ), rowing (m: $58.1 \mathrm{~kg} ; \mathrm{w}: 31.9 \mathrm{~kg}$ ), bench press (m: $75.0 \mathrm{~kg}$; w: $33.8 \mathrm{~kg}$ ) and knee flexion $\left(90^{\circ}\right)(\mathrm{m}: 82.1 \mathrm{~kg} ; \mathrm{w}: 44.7 \mathrm{~kg})$. The result of the sit and reach test was $7.8 \mathrm{~cm}$ for male subjects and $16.2 \mathrm{~cm}$ for female athletes.
\end{abstract}

Keywords: dance; rock ' $n$ ' roll; acrobatics; anthropometry; BIA; BMI; 1RM; jumping power 


\section{INTRODUCTION}

The history of rock ' $n$ ' roll began in the early 1920s in the United States, and by now it has become a worldwide popular dance in $4 / 4$ time. In addition to the popular recreational sport, there is a spectacular tournament variant with numerous acrobatic elements such as kicks, rolls, somersaults and screws. The dance is a harmonious mix of elegance, dynamics and risk. These are the special elements of this sport.

National and international tournaments are divided into six classes of socalled "safety levels" up to the "main class" (class A) according to their difficulty of acrobatics. At the premier level acrobatics lasts 1.5 minutes. During this time, six acrobatic elements must be demonstrated at $48-50$ cycles per minute and a foot technique (one minute) at 50-52 cycles per minute.

Typical injury patterns in rock ' $n$ ' roll include stress fractures in the foot, ankle sprain, periostitis of the lower leg, knee injury, hamstring injury, chronic back pain, vertebral fractures, concussion and neck injuries, blunt abdominal trauma, and side ligament ruptures of the thumb in men.

There are two important reasons for that. First, lack of clarity in the execution of an acrobatic figure or, second, physical weakness. The latter is due to the amateurish circumstances of this sport. No professional sportsmen can ignore unspecific preventive practice sessions to take care of injury prophylaxis or to eliminate muscular imbalances. In order to break new ground in this area, the authors have investigated the status quo of the Austrian national team. Following these tests, there should be exercise interventions to implement for top athletes, and a prevention programme for the youth will be developed. For longitudinal data collection, a study will also be conducted in the future.

\section{MATERIALS AND METHODS}

The Austrian national rock 'n' roll team consisted of 26 (w: 13; m: 13) A-, Band C-level athletes. Six subjects were A-class, $17 \mathrm{~B}$-class and three C-class associates. The athletes were all amateurs and trained between 2-5 hours, on average four hours of any kind of sport per week. Extra training in athletics was taken only by $5 \%$ of the participants.

\section{Bioelectrical impedance analysis (BIA)}

In this study, only international standards were used $[1,2]$. The "NAiS Body Fat Watcher" (Matsushita Electric Works, Ltd, Osaka, Japan) is a device that operates on the basis of bioelectrical impedance analysis (BIA). BIA is based on 
the principle that the human body exerts resistance to electric current. There is the fat mass of the lean body in the mass of the body. The fat mass is a poor conductor. In contrast, the lean body mass is a good conductor of current due to its high water content [3].

\section{Jumping}

The jump mat of the company Ishe (www.ishe.de) was used to determine the height of the counter movement jump (CMJ) and the squat jump (SQJ). The software detects the contact time and also the flight time of a jump. From the determined flight time, the jump height can be calculated [5]. All the athletes had to perform three jumps. The best jump went into the calculations.

\section{The Broca index}

The Broca index is calculated as follows $[4,5]$ :

$$
\begin{aligned}
& \mathrm{M}=\mathrm{kg} \times 100 /(\mathrm{h} \mathrm{cm}-100) \\
& \mathrm{W}=\mathrm{kg} \times 100 /(\mathrm{h} \mathrm{cm}-110)
\end{aligned}
$$

Categorization (\%):

$\begin{array}{ll}\text { Underweight } & <-18 \\ \text { Normal Weight } & -18-11 \\ \text { Slightly overweight } & 12-22 \\ \text { Severely overweight } & 23-33 \\ \text { Obesity I } & 34-55 \\ \text { Obesity II } & 56-77 \\ \text { Obesity III } & >78\end{array}$

\section{AKS-Index}

First, the body active substance is determined by converting the percentage of fat into the absolute fat mass and then subtracted from the total mass of the body.

$$
\mathrm{PB}=\text { body weight }(\mathrm{g})-\text { fat }(\mathrm{g})
$$

The index is the quotient of the AKS and the body height.

$$
\text { AKS-index }=(\mathrm{g}) \times 100 / \text { body height }{ }^{3}\left(\mathrm{~cm}^{3}\right)
$$




\section{RESULTS}

Table 1. Anthropometric measurements

\begin{tabular}{lcccc}
\hline & \multicolumn{2}{c}{ Men } & \multicolumn{2}{c}{ Women } \\
\cline { 2 - 5 } & Mean & SD & Mean & SD \\
\hline Height $(\mathrm{cm})$ & 181 & 7 & 164 & 10 \\
\hline Weight $(\mathrm{kg})$ & 76.2 & 9.0 & 53.4 & 9.7 \\
\hline BIA (\%) & 15.8 & 2.3 & 23.5 & 3.7 \\
\hline Hip/waste ratio & 0.9 & & 0.9 & \\
\hline BMI $\left(\mathbf{k g} / \mathbf{m}^{2}\right)$ & 19.8 & & 23.3 & \\
\hline Broca index & 6.0 & & 1.2 & \\
\hline AKS index & 1.02 & & 0.91 \\
\hline
\end{tabular}

Table 2. Jump results

\begin{tabular}{lcccc}
\hline & \multicolumn{2}{c}{ Men } & \multicolumn{2}{c}{ Women } \\
\cline { 2 - 5 } & Mean & SD & Mean & Sd \\
\hline SQJ (cm) & 37.1 & 6.3 & 25.8 & 4.9 \\
\hline CMJ (cm) & 41.9 & 6.3 & 27.2 & 5.3 \\
\hline Long jump (cm) & 256.0 & 29.4 & 204.6 & 26.1 \\
\hline
\end{tabular}

Table 3. Strength and flexibility values

\begin{tabular}{lcccccc}
\hline & \multicolumn{3}{c}{ Men (1 RM kg) } & \multicolumn{3}{c}{ Women (1 RM kg) } \\
\cline { 2 - 7 } & Mean & SD & $\begin{array}{c}\text { Kg/kg body } \\
\text { weight }\end{array}$ & Mean & SD & $\begin{array}{c}\text { Kg/kg body } \\
\text { weight }\end{array}$ \\
\hline Pulldown & 76.9 & 7.0 & 1.0 & 39.4 & 5.0 & 0.73 \\
\hline Rowing & 58.1 & 8.0 & 0.76 & 31.9 & 2.6 & 0.59 \\
\hline Bench press & 75.0 & 12.5 & 0.98 & 33.8 & 5.5 & 0.63 \\
\hline Knee flexion & 82.1 & 11.9 & 1.07 & 44.7 & 4.3 & 0.83 \\
\hline Sit and reach $(\mathrm{cm})$ & +7.8 & 5.6 & & +16.2 & 4.0 & \\
\hline
\end{tabular}

\section{AKS index}

The AKS index was 1.02 for men and 0.91 for women. 


\section{DISCUSSION}

\section{Anthropometric data}

The studies by Raschka (2006) describe dancers as athletes with a uniform physique. All women and men in these studies have similar body composition features. Our findings confirm that. The data found by Wanke et al. [7] show the rock ' $n$ ' rollers' comparable body height, tissue layers and BMI. In acrobatics, it seems biomechanically ideal to generate a high release point. This can be most easily reached by a large man with a lot of power. Women should inferentially be small and light to be comparably "easy" to drop in rotations, for example, double somersault and double screw.

Women generally have less muscle mass and a higher percentage of fat than men [10]. On average, normal-weight young women have $20-35 \%$ fat of body weight, while men have $8-22 \%$. Thus, on average, women have a 1.75 times greater fat mass than men [12]. The values found by the BIA measurement confirmed that in our sample this difference was 1.49 times. A comparison with body fat values of other aesthetic compensatory sports shows higher levels for rock ' $n$ ' roll dancers (Table 4). The reason may be the small number of training interventions in rock ' $n$ ' roll.

Table 4. Body fat values in aesthetic compensatory sports

\begin{tabular}{lcc}
\hline BIA (\%) & Men & Women \\
\hline Rock ' $n$ ' Roll (26) & 15.8 & 23.5 \\
\hline Dance (20) & 13.1 & 21.9 \\
\hline Contemporary Dance (2) & 12.9 & 21.2 \\
\hline Rhythmic gymnastics (19) & - & 14.3 \\
\hline Ballet (20) & 12.7 & 17.5 \\
\hline
\end{tabular}

\section{Energy consumption and cardiovascular stress}

Léger [13] confirms that, at a dance session, energy consumption per hour is $2900 \mathrm{~kJ}$ in men and $1900 \mathrm{~kJ}$ in women. If we take these values as a basis, we are more likely to accept that the lowest level of energy consumption at a rock ' $n$ ' roll competition is significantly higher. In 1.5 minutes of dance time, an A-class couple must perform six acrobatic elements. According to the above assumption, male athletes have energy consumption of $72.5 \mathrm{~kJ}$ or $48.3 \mathrm{~kJ} / \mathrm{min}$ (female athletes $47.5 \mathrm{~kJ}$ or $31.6 \mathrm{~kJ} / \mathrm{min}$ ). 
The time between the acrobatics is characterized by a rapid change of direction, turns and kicks. Blanksby and Reidy [14] found in their studies of Latin American and modern dance that energy expenditure in men was $54.1 \mathrm{~kJ} / \mathrm{min}$ in modern and $54.0 \mathrm{~kJ} / \mathrm{min}$ in Latin American dances. In women, these indicators were $34.7 \mathrm{~kJ} / \mathrm{min}$ in modern and $36.1 \mathrm{~kJ} / \mathrm{min}$ in Latin American dances. These data confirm our assumption of comparable minimum energy consumption during a rock ' $n$ ' roll competition dance sequence. Next, investigations must be undertaken to support this assumption.

\section{Bounce and power values}

The great need for sport is reflected in bounce in women and leg strength in men. Preventive leg axis training, resistance training and jump training are considered essential. Motor deficits of the lower extremities in combination with a valgus axis could explain the knee problems of athletes (unpublished interview questions).

The values of bounce measurement attest to the athletes an excellent bounce compared to the general population. The comparison with other sports places the rock ' $n$ ' rollers in the area of sport students and middle distance runners [15]. Consequently, individualised weight training is recommended to optimise performance. Studies $[20,21]$ have shown that explicit plyometric and strength training resulted in significant performance gains in ballet dancers, which they could then translate into better performance. An equivalent proposal can be affirmed by the authors for their subjects.

In international comparison, the found strength values per kilogram of body weight are considered a beginner's performance in weight training. There is clearly a need for the optimisation of squat strength [16, 17]. Lack of strength in the lower extremities prevents huge boost in men and dynamic footsteps in preparation for jumps in women. Only satisfactory power capacity of the upper limbs of men completes the picture of too little strength. Achieving a high altitude is called into question, so the woman can have less time to complete her acrobatic figure before gravity brings her down.

\section{CONCLUSIONS}

As in other sports, starting at an early age is also ideal in rock ' $n$ ' roll. Here the sport offers opportunities of early motor and cognitive intervention [8]. In the future, the shortcomings in athletic abilities have to be consistently worked on to give youngsters adequate protection and prevention during their sports careers. 
Sports specific training alone cannot compensate strength deficits in rock ' $n$ ' roll. Additional resistance training is advised. Further studies, especially in terms of performance physiology can be recommended.

\section{LITERATURE}

1. Martin R. \& Knußmann R. (1988). Anthropologie, Handbuch der vergleichenden Biologie des Menschen, Band I. Stuttgart: Fischer Verlag.

2. Martin R. \& Saller K. (1957). Lehrbuch der Anthropologie, 3. Auflage. Stuttgart: Fischer Verlag.

3. Heyward V., Stolarczyk L. (1996). Applied body composition assessment. Human kinetics.

4. Deutsche Gesellschaft für Arbeitsmedizin und Umweltmedizin e.V. (DGAUM) (2000). Leitlinien Messung des Fettgehaltes des menschlichen Körpers, Erarbeitet von: Restorff W Zentrales Institut des Sanitätsdienstes der Bundeswehr, Koblenz.

5. Raschka C. (2006). Sportanthropologie. Köln: Sportverlag Strauß.

6. Deutsche Gesellschaft für Sport und Prävention: S 1- Leitlinie Vorsorgeuntersuchung im Sport (2007).

7. Wanke EM et al. (2014). Tanzsport: Verletzungsmuster im Lateinamerikanischen Formationstanz. Sportverl Sportschad, 28 (3), 132-138.

8. Mai D. (2014). Mama, ich möchte tanzen! Der altersgerechte Einstieg in die Welt des Tanzes. Diplomica Verlag.

9. Allgemeiner Sportverband Österreich ASVÖ (2006), 137-138.

10. Jürgens H.W., Matzdorff I., Windberg J. (1998). International anthropometric data for work-place and machinery design. Arbwiss. Erk. No 108, BAA Dortmund.

11. Yannakoulia M., Kerramopopoulos A., Tsakalakos N. and Matalas A. (2000). Body composition in dancers: the bioelectrical impedance method. Med Sci Sports Exerc, 32(1), 228-234.

12. Angerer T. (2013). Sportmedizinische Betrachtung sporttreibenden Frau. Ebook, Hausarbeit.

13. Léger L.A. (1982). Energy cost of disco dancing. Res Q Exerc Sport, 53, 46-49.

14. Blanksby B. Reidy P. (1988). Heart rate and estimated energy expenditure during ballroom dancing. Br J Sports Med, 22, 57-60.

15. Bant H., Haas, H-J., Ophey M., Steverding M. (2011). Sportphysiotherapie. Thieme Verlag, S. $94 f$.

16. www.exrx.net (2015).

17. www.fitness-experts.de (2015).

18. Friedrich W. (2007). Optimales Sportwissen. Spitta Verlag. 
19. Klentrou P., Plyley M. (2003). Onset of puberty, menstrual frequency, and body fat in elite rhythmic gymnasts compared with normal controls. Br J Sports Med, 37, 490-494.

20. Liiv H., Wyon M.A., Jürimäe T., Saar M., Mäestu J., Jürimäe J. (2013). Anthropometry, somatotypes, and aerobic power in ballet, contemporary dance, and dancesport. Med Probl Perform Art, 28(4), 207-211.

21. Brown A.C., Wells T.J., Shade M.L., Smith D.L., Fehling P.C. (2007). Effects of plyometric training versus traditional weight training on strength, power, and aesthetic jumping ability in female collegiate dancers. J Dance Med Sci, 11, 38-44.

22. Koutedakis Y., Hukam H., Metsios G., Nevill A., Giakas G., Jamurtas A., Myszkewycz L. (2007). The effects of three months of aerobic and strength training on selected performance and fitness-related parameters in modern dance students. J Strength Cond Res, 21, 808-812.

\section{Address for correspondence:}

Dr. Jürgen Fritzsche

German Karate Federation (DKV)

An den Tannen 34

D-61250 Usingen

Germany

E-mail: Fritzsche_J@web.de 